\title{
IMPLEMENTASI IJĀRAH DAN IMBT PADA BANK BRI SYARIAH CABANG YOGYAKARTA
}

\author{
Mila Sartika \& Hendri Hermawan Adinugraha ${ }^{1}$
}

\begin{abstract}
The development of Islamic banking is relatively significant modifications to the current demands of product variants resulted in raising funds and financing at Islamic banking. The concept of ijärah and ijärah muntabiyah bi al-tamlike (IMBT) both are one example of financial products and services in Islamic banking. By the mindless, this paper aims to describe the concept of ijärah and IMBT on Islamic banking and explained at the level of practice and compliance with the law analyze normative (al-Qur'an, Hadith, and the MUI Fatwa/DSN) and positive law (the Compilation of Sharia Economic Law which issued by the Supreme Court). This research uses a field of research that is descriptive analytical study then combined with the library to produce a comprehensive description of the ijarah and IMBT. Data analysis techniques starting from the identification of problems, data collection, solve problems which eventually led to the solution in the form of a conclusion. From the findings it can be concluded that the implementation of ijarah and IMBT as financing products at Bank BRI Syariah Cabang Yogyakarta is done by the bank to buy what is desired by the customer (such as home and vebicle), then rent it to their bank, at the end of the contract/agreement the bank gives them the option, to have the leased goods bought by way of BRI Sharia (IMBT), or by handing it back to BRI sharia (ijarah). In practice, the operational foundation based on the Sharia Board of the National Fatwa No. 09/DSNMUI/IV2003 the Compilation Economics and Shariah Law Chapter XI of ijärah and IMBT.
\end{abstract}

Keywords: ijārah; ijärah muntabiyah bi al-tamlīk.

\section{Pendahuluan}

Pada hakikatnya, faktor utama munculnya perbankan syariah di dunia Islam ialah karena merebaknya "bunga". Yang mana bunga secara fikih dikategorikan sebagai riba dan hukumnya haram, maka mulai timbul usahausaha di sejumlah negara muslim untuk mendirikan lembaga alternatif terhadap bank yang ribawi (konvensional).

\footnotetext{
${ }^{1}$ Dosen Universitas Dian Nuswantoro Semarang
} 
Implementasi Ijärah dan IMBT...

Selanjutnya, sifat dasar transaksi bank syariah yang merupakan investasi, jual beli, dan sangat variannya pelaksanaan pembiayaan yang dapat dilakukan oleh perbankan syariah, seperti pembiayaan dengan prinsip murābahah (jual beli), ijärah (sewa) atau ijärah wa iqtinā' atau ijärah muntahiyah bi al-tamlīe (sewa beli) dan lain-lain.

Produk pembiayaan ijärah pada bank syariah dan lembaga keuangan syariah lainnya, termasuk dalam katagori natural certainty contracts dan pada dasarnya adalah akad jual beli. Dalam pembiayan ijärah, objek transaksinya adalah jasa, baik manfaat atas barang maupun manfaat atas tenaga kerja, sehingga dengan skema ijärah, bank syariah dan lembaga keuangan syari'ah lainnya dapat melayani nasabah yang membutuhkan jasa. ${ }^{2}$

Bentuk pembiayaan ijärah merupakan salah satu teknik pembiayaan ketika kebutuhan pembiayaan investor untuk membeli aset terpenuhi dan investor hanya membayar sewa pemakaian tanpa harus mengeluarkan modal yang cukup besar untuk membeli aset tersebut. Secara umum timbulnya ijärah disebabkan oleh adanya kebutuhan (need) akan barang atau manfaat barang oleh nasabah yang tidak memiliki kemampuan keuangan.

Hal ini selaras dengan strategi bisnis PT BRISyariah yang sudah dicanangkan mulai 2010 - 2014 yaitu: conventional business, growth business, dan innovative business. ${ }^{3}$ Kemudian diperkuat oleh pernyataan Direktur Utama PT. Bank BRISyariah, Moch. Hadi Santoso, dalam laporannya bahwa jumlah penyaluran pembiayaan PT Bank BRISyariah meningkat 26,43\%, yaitu dari Rp. 9,17 triliun menjadi Rp. 11,40 triliun di tahun 2012. Porsi terbesar pembiayaan disalurkan kepada segmen Mikro, Retail \& Linkage 39,07\%, konsumer sebesar $31,63 \%$ dan selebihnya disalurkan kepada pembiayaan komersial sebesar $29,30 \%{ }^{4}$

Jika dilihat dari historisnya, pada mulanya transaksi ijärah dilandasi adanya perpindahan manfaat (hak guna), bukan perpindahan kepemilikan (hak milik). Jadi pada dasarnya prinsip ijärah sama saja dengan prinsip jual beli tapi

\footnotetext{
hlm. 2.

2 Tatang Sutardi, "Ijarah (Aplikasinya Pada Lembaga Keuangan Syari'ah)”, Makalah, t.t.p, 2008,

3 (http://www.brisyariah.co.id/?q=faq-perbankan-syariah)

4 Laporan Tahunan BRI Syariah tahun 2012, hlm. 23.
} 
perbedaannya terletak pada objek transaksinya. Bila pada jual beli objek transaksinya barang, sedangkan pada ijärah objek transaksinya adalah manfaat barang dan jasa.

Kemudian akad ijärah ini dimodifikasi dengan dasar kebutuhan masyarakat yang kian melonjak. Sehingga ada akad sewa yang berakhir dengan kepemilikan atau yang biasa disebut dengan ijärah wa iqtinā atau ijärah muntabiyah bi al-tamlīe (financing hire purchase), dua akad bersamaan dalam satu transaksi. Di sini terdapat dua akad yaitu ijärah (sewa) dan bay' (pembelian), akan tetapi terkumpul di antara keduanya dalam satu transaksi jual beli dengan satu harga. Dan tentunya harga harus diketahui oleh kedua belah pihak yang bersangkutan (mujir/muäjir (yang menyewakan) dan mustajì (penyewa), sebagaimana yang dikatakan oleh Ja'far al-Dimsyaqi: “sesungguhnya setiap barang dan jasa yang dapat dijual serta disewa, hendaknya harus memiliki nilai yang diketahui oleh para pelakunya, maka dengan begitu akan terjadi tawarmenawar pada proses tersebut, sehingga bisa menjadi murah bahkan menjadi mahal yang relatif sesuai dengan kemampuannya". Hal ini selaras dengan sabda Nabi saw yang diriwayatkan oleh Ibn Majah: "ghalat al-ibilu wa hānat". .

Untuk mencoba memahami lebih mendalam pengertian dari konsep kontrak ijärah, dan untuk mengenal lebih dekat bagaimana sistem penerapannya pada bank syariah, kemudian timbul pertanyaan, apakah ada dasar hukum syar'i pada akad ijärah dan IMBT? Dan apakah muamalah ini diperbolehkan menurut syar'i? serta bagaimana aplikasinya pada Bank BRI Syariah?

\section{Metode Penelitian}

Penelitian ini menggunakan jenis penelitian lapangan (field research) yang bersifat deskriptif analitis. ${ }^{6}$ Artinya memaparkan data dan fakta mengenai ijärah dan IMBT selanjutnya menganalisisnya untuk mendapatkan jawaban dari rumusan masalah yang sudah dibuat. Penelitian ini juga dilengkapi dengan penelitian pustaka (library research) untuk menghasilkan deskripsi yang komprehensif mengenai ijärah dan IMBT.

\footnotetext{
5 Rafiq Yunus al-Mishry, Ushūl al-Iqtishād al-Islämy, Cetakan ke-3, Damaskus: Dār al-Qalam, 1999, hlm. 128

${ }^{6}$ Lexy J. Moeleong, Metodologi Penelitian Kualitatif, Bandung: Remaja Rosdakarya, 1990, hlm. 18.
} 
Implementasi Ijärah dan IMBT...

Model kerangka pemikiran yang digunakan untuk menganalisis data dan fakta mengenai ijärah dan IMBT dapat digambarkan sebagai berikut:

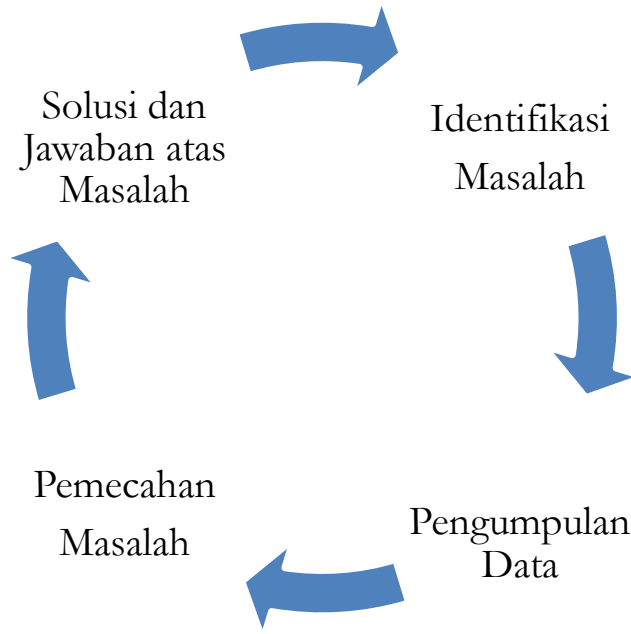

Gambar 2.1 Proses Analisis Data

\section{Definisi ljārah dan ljārah Muntahiyah Bi al-Tamlīk}

Al-Tajīir menurut bahasa diambil dari kata al-ajr, yaitu imbalan atas sebuah pekerjaan, dan juga dimaksudkan dengan pahala. Adapun al-ijärah adalah nama untuk upah, yaitu suatu yang diberikan berupa upah terhadap pekerjaan. ${ }^{7}$. Untuk lebih jelasnya, di bawah ini akan dikemukakan beberapa definisi ijärah menurut perspektif beberapa ulama fikih, yaitu:

a) Ulama Hanafiah

Artinya akad atas suatu kemanfaatan dengan pengganti.

b) Ulama Syafi'iyah

Artinya akad atas suatu kemanfaatan yang mengandung maksud tertentu dan mubah, srta menerima pengganti atau kebolhan dengan penganti tertentu.

c) Ulama Malikiyah dan Hanabilah

Artinya menjadikan milik suatu kemanfaatan yang mubah dalam waktu tertentu dengan pengganti.

7 al-Musyaiqih, http:// mmw.direk.toriislam.com, diakses 11 Maret 2014. 
Sedangkan jjärah menurut jumhur ialah berarti sewa, jasa atau imbalan, yaitu akad yang dilakukan atas dasar suatu manfaat dengan imbalan jasa. ${ }^{8}$. Menurut Sayyid Sabiq, ijārah adalah suatu jenis akad yang mengambil manfaat dengan jalan penggantian. ${ }^{9}$ Dengan demikian pada hakikatnya ijärah adalah penjualan manfaat yaitu pemindahan hak guna (manfaat) atas suatu barang dan jasa dalam waktu tertentu melalui pembayaran sewa/biaya sewa tanpa diikuti dengan pemindahan kepemilikan barang itu sendiri. Akad jjärah tidak ada perubahan kepemilikan tetapi hanya perpindahan hak guna/manfaat saja dari yang menyewakan kepada penyewa.

Secara definitif dalam akad ijärah tidak ada perubahan kepemilikan tetapi hanya perpindahan hak guna saja dari yang menyewakan kepada penyewa. Dalam Hukum Islam ada dua jenis ijärah, yaitu: ${ }^{10}$

a) Ijärah yang berhubungan dengan sewa jasa, yaitu mempekerjakan jasa seseorang dengan upah sebagai imbalan jasa yang disewa. Pihak yang mempekerjakan disebut mustajīr, pihak pekerja disebut äjir dan upah yang dibayarkan disebut ujrah.

b) Ijärah yang berhubungan dengan sewa aset atau properti, yaitu memindahkan hak untuk memakai dari aset atau properti tertentu kepada orang lain dengan imbalan biaya sewa. Bentuk ijärah ini mirip dengan leasing (sewa) pada bisnis konvensional. Pihak yang menyewa (lessee) disebut mustajīr, pihak yang menyewakan (lessor) disebut mu'jir/muäjir dan biaya sewa disebut ujrah.

Ijärah bentuk pertama banyak diterapkan dalam pelayanan jasa perbankan syariah, sementara ijärah bentuk kedua biasa dipakai sebagai bentuk investasi atau pembiayaan di perbankan syariah.

Sedangkan ijärah wa iqtinä' atau ijärah muntahiyah bi at-tamlïk atau akad sewa menyewa yang berakhir dengan kepemilikan merupakan sebuah istilah modern yang tidak asing lagi pada saat ini. Istilah definitifnya tersusun dari dua kata, yaitu;

8 Habib Nazir dan Muh. Hasan, Ensiklopedi Ekonomi dan Perbankan Syariah. Bandung: Kaki Langit, 2004, hlm. 246.

9 Sayyid Sabiq, Fiqh al-Sunnah. jilid 3, Beirut: Dār al-Kitāb al-Araby, 1983, hlm. 177.

${ }^{10}$ Ascarya, Akad dan Produk Syari'ah, Jakarta: PT. Raja Grafindo Persada, 2007, hlm. 99. 
Implementasi Ijärah dan IMBT...

a. al-Tajìr / al-ijärah (sewa)

b. al-Tamlike (kepemilikan)

Kata al-tamlike secara bahasa memiliki arti menjadikan orang lain memiliki sesuatu. Adapun menurut istilah (terminologi) ia tidak keluar dari maknanya secara bahasa. Dan al-tamlik bisa berupa kepemilikan terhadap benda, kepemilikan terhadap manfaat, bisa dengan ganti atau tidak. Istilah tersebut dapat dibedakakan dalam beberapa katagori berikut ini:

a. Jika kepemilikan terhadap sesuatu terjadi dengan adanya ganti maka ini adalah jual beli.

b. Jika kepemilikan terhadap suatu manfaat dengan adanya ganti maka disebut persewaan.

c. Jika kepemilikan terhadap sesuatu tanpa adanya ganti maka ini adalah hibah/pemberian.

d. Adapun jika kepemilikan terhadap suatu manfaat tanpa adanya ganti maka disebut pinjaman.

Dari beberapa paparan definisi di atas, maka dapat diambil definisi inti dari ijärah muntabiyah bi al-tamlike terdiri dari dua kata yaitu kepemilikan suatu manfaat (jasa) berupa barang yang jelas dalam tempo waktu yang jelas, diikuti dengan adanya pemberian kepemilikan suatu barang yang bersifat khusus dengan adanya perpindahan hak, dari hak sewa menjadi hak milik. Hal ini sesuai dengan kaedah fikih:"1 "mà shabha an yumlika bil al-akbdzi shabha an yumlika bil bay'i”. Maknanya ialah bahwa apa-apa yang dapat diambil manfaatnya, maka dapat pula dijual. Dengan pengecualian, selama barang atau jasa tersebut tidak bertentangan dengan hukum Islam.

Secara rinci, prinsip ujrah (ijärah) dapat dilihat pada tabel di bawah ini:

11 Muhammad al-Ruky, Qawäid al-Figh al-Islāmy min Khiläl Kitāb "al-Isyrāf 'alā Masāil al-Khiläf” alQādhi Abd al-Wahhāb al-Baghdadi al-Mälikey, jilid I, Damaskus: Dār al-Qalam, 1998, hlm. 250. 
Tabel 3.1

Prinsip Ujrah (Ijārah)

\begin{tabular}{|l|l|l|}
\hline No & Akad & Definisi \\
\hline 1 & Ijärah & $\begin{array}{l}\text { Akad sewa menyewa barang antara } \\
\text { bank syariah (muäjir) dengan penyewa } \\
\text { (mustajir). Setelah masa sewa berakhir } \\
\text { barang sewaan dikembalikan kepada } \\
\text { muäjir. }\end{array}$ \\
\hline 2 & $\begin{array}{l}\text { Ijärah muntahiyah bi al- } \\
\text { tamlike (IMBT) }\end{array}$ & $\begin{array}{l}\text { Akad sewa menyewa barang antara } \\
\text { bank (muäjir) dengan penyewa } \\
\text { (mustajir) yang diikuti janji bahwa } \\
\text { pada saat yang ditentukan } \\
\text { kepemilikan barang sewaan akan } \\
\text { berpindah kepada mustajir. }\end{array}$ \\
\hline
\end{tabular}

\section{Dasar Syar'i ljārah}

Ijärah sebagai suatu transaksi yang sifatnya saling tolong menolong mempunyai landasan yang kuat dalam al-Qur'an dan hadis. Landasan filosofi konsep ini mulai ada dan dikembangkan pada masa khalifah Umar bin Khattab yaitu ketika adanya sistem bagian tanah dan adanya langkah revolusioner dari khalifah Umar yang melarang pemberian tanah bagi kaum muslim di wilayah yang ditaklukkan. Dan sebagai langkah alternatif adalah membudidayakan tanah berdasarkan pembayaran kharäj (pajak tanah) dan jisyah (pajak dari nonmuslim).

Adapun yang menjadi dasar hukum ijaräh adalah: ${ }^{12}$

a. Al-Qur'an:

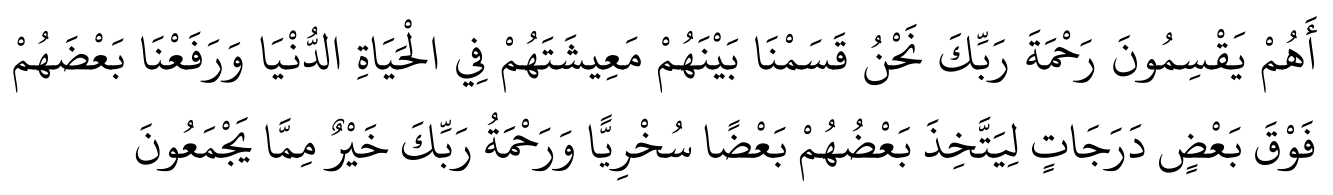

12 Tim Penulis Dewan Syari'ah Nasional (DSN) MUI, Himpunan Fatwa Dewan Syari'ah Nasional, Jakarta: PT. Intermasa, 2003, hlm. 54

Volume VII/Edisi 1/Mei 2016 
Implementasi Ijärah dan IMBT...

“Apakah mereka yang membagi-bagikan rahmat Tuhanmu? Kami telah menentukan antara mereka penghidupan mereka dalam kehidupan dunia, dan kami telah meninggikan sebagian mereka atas sebagian yang lain beberapa derajat, agar sebagian mereka dapat mempergunakan sebagaian yang lain. Dan rahmat Tuhanmu lebih baik daripada apa yang mereka kumpulkan”. (QS. al-Zukhruf [43]:32).

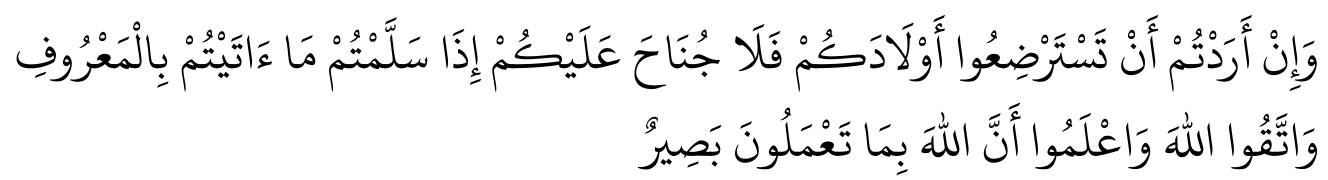

“...dan jika kalian ingin anakmu disusukan oleh orang lain, tidak dosa bagimu apabila kalian memberikan pembayaran menurut yang patut. Bertakwalah kepada Allah; dan ketahuilah bahwa Allah Maha Melihat apa yang kalian kerjakan". (QS. Al-Baqarah [2]:233)

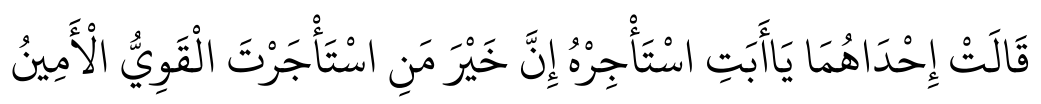

"Salah seorang dari kedua wanita itu berkata: Hai ayahku, ambilah ia sebagai orang yang bekerja pada (kita), karena sesungguhnya orang yang paling baik yang kamu ambil untuk bekerja (pada kita) adalah orang yang kuat lagi dapat dipercaya" (QS. al-Qashash [28]:26)

b. Hadis

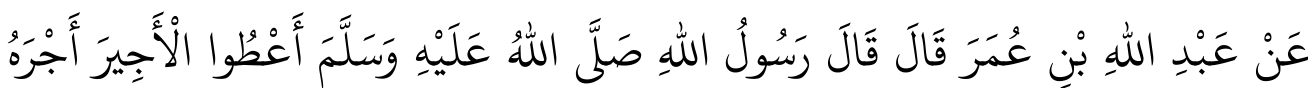

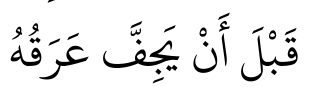

"Dari Abdullah bin Umar bahwa Rasulullah saw bersabda: Berikanlah upah kepada pekerja sebelum keringatnya kering”. (HR. Ibnu Majah).

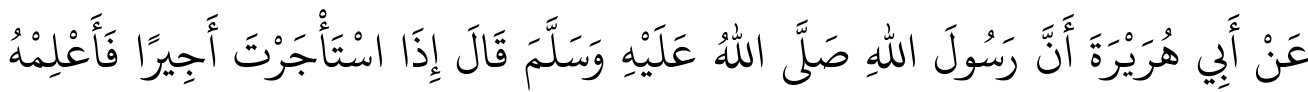

"Dari Abu Hurairah bahwa Rasulullah saw bersabda: Apabila kamu mengangkat pekerja maka beritahukanlah upahnya". (HR. Abdur Razaq)

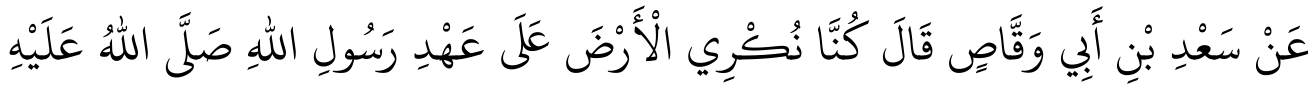

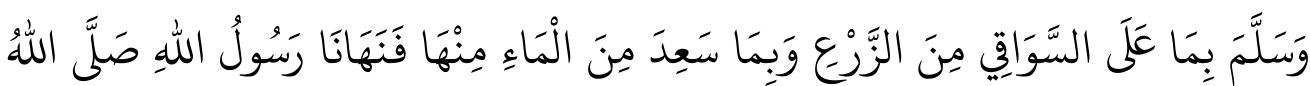

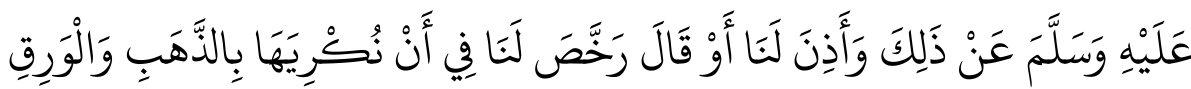


"Dari Sa'd bin Abi Waqqash, di berkata: Kami pernah menyewakan tanah pada masa Rasulullah saw dengan (bayaran) hasil pertaniannya, maka Rasulullah saw melarang kami melakukan hal tersebut dan mengizinkan kami menyewakannya dengan emas atau perak". (HR. Al-Darimi).

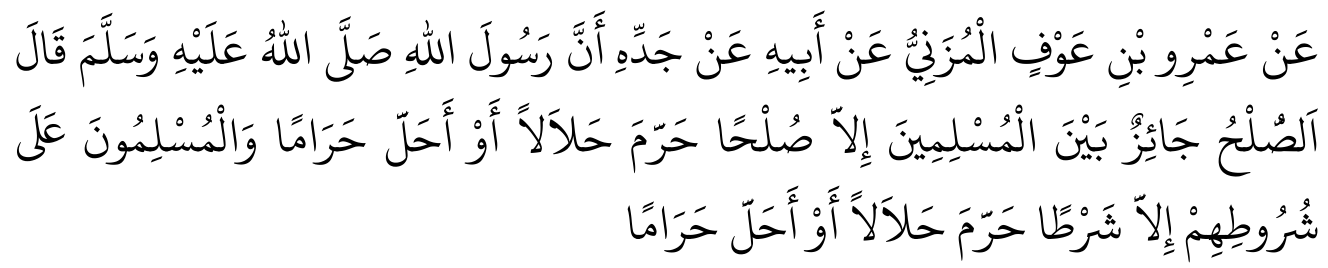

"Dari Amr bin Auf dari ayahnya dari kakeknya bahwa Rasulullah saw bersabda: Perdamaian dapat dilakukan di antara kaum muslimin kecuali perdamaian yang mengharamkan yang halal atau menghalalkan yang haram; dan kaum muslimin terikat dengan syarat-syarat mereka kecuali syarat yang mengharamkan yang halal atau menghalalkan yang haram". (HR. Tirmidzi)

c. Ijma' ulama tentang kebolehan melakukan akad sewa menyewa.

d. Kaidah fiqh.

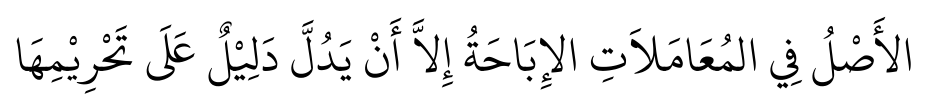

"Pada dasarnya semua bentuk muamalah boleh dilakukan kecuali ada dalil yang mengharamkannya."

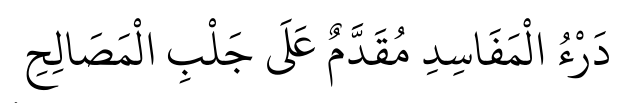

"Menghindarkan mafsadat (kerusakan/bahaya) harus didahulukan atas mendatangkan kemaslahatan."

\section{Ketentuan Akad ljärah}

Dalam fatwa Dewan Syariah Nasional Nomor 09/DSNMUI/IV2000 tanggal 13 April 2000 tentang Pembiayan Ijarah ditetapkan:13

1. Rukun dan Syarat Ijärah:

a. Pernyataan ijab dan qabul.

${ }^{13}$ Ibid, hlm. 55 
Implementasi Ijärah dan IMBT...

b. Pihak-pihak yang berakad (berkontrak): terdiri atas pemberi sewa (lessor, pemilik aset, Lembaga Keuangan Syariah) dan penyewa (lessee, pihak yang mengambil manfaat dari penggunaan aset, nasabah).

c. Objek kontrak : pembayaran (sewa) dan manfaat dari penggunaan aset.

d. Manfaat dari penggunaan aset dalam ijärah adalah objek kontrak yang harus dijamin, karena ia rukun yang harus dipenuhi sebagai ganti dari sewa dan bukan aset itu sendiri.

e. Sighat ijärah adalah berupa pernyataan dari kedua belah pihak yang berkontrak, baik secara verbal atau dalam bentuk lain yang equivalent, dengan cara penawaran dari pemilik aset (lembaga keuangan syariah) dan penerimaan yang dinyatakan oleh penyewa (nasabah).

2. Ketentuan Objek Ijärah:

a. Objek ijärah adalah manfaat dari penggunaan barang dan atau jasa.

b. Manfaat barang harus bisa dinilai dan dapat dilaksanakan dalam kontrak.

c. Pemenuhan manfaat harus yang bersifat dibolehkan.

d. Kesanggupan memenuhi manfaat harus nyata dan sesuai dengan syariah.

e. Manfaat harus dikenali secara spesifik sedemikian rupa untuk menghilangkan jahälah (ketidak tahuan) yang akan mengakibatkan sengketa.

f. Spesifikasi manfaat harus dinyatakan dengan jelas, termasuk jangka waktunya. Bisa juga dikenali dengan spesifikasi atau identifikasi fisik.

g. Sewa adalah sesuatu yang dijanjikan dan dibayar nasabah kepada lembaga keuangan syariah sebagai pembayaran manfaat. Sesuatu yang dapat dijadikan harga dalam jual beli dapat pula dijadikan sewa dalam ijärah.

h. Pembayaran sewa boleh berbentuk jasa (manfaat lain) dari jenis yang sama dengan objek kontrak.

i. Kelenturan (flexibility) dalam menentukan sewa dapat diwujudkan dalam ukuran waktu, tempat dan jarak. 
3. Kewajiban Lembaga Keuangan Syariah (LKS) dan Nasabah dalam Pembiayaan Ijärah :

3.1. Kewajiban Lembaga Keuangan Syariah sebagai pemberi sewa :

a. Menyediakan aset yang disewakan.

b. Menanggung biaya pemeliharaan aset.

c. Penjamin bila terdapat cacat pada aset yang disewakan.

3.2. Kewajiban nasabah sebagai penyewa :

a. Membayar sewa dan bertanggung jawab untuk menjaga keutuhan aset yang disewa serta menggunakannya sesuai dengan kontrak.

b. Menanggung biaya pemeliharaan aset yang sifatnya ringan (materil) Jika aset yang disewa rusak, bukan karena pelanggaran dan penggunaan yang dibolehkan, juga bukan karena kelalaian pihak penyewa dalam menjaganya, ia tidak bertanggung jawab atas kerusakan tersebut.

\section{ljärah Muntahiyah Bi al-Tamlīk dan Perkembangannya}

Dalam konteks perbankan syariah masa kini IMBT diadopsi oleh leasing sehingga praktiknya di lapangan hampir sama. ${ }^{14}$ Sebab al-bay' wa ijärah muntahiyah bi al-tamlike merupakan rangkaian dua buah akad, yakni akad al-bay' dan akad ijärah muntahiyah bi al-tamlik. Al-bay' merupakan akad jual beli, sedangkan ijārah muntahiyah bi al-tamlike merupakan kombinasi sewa menyewa (jjärah) dan jual beli atau hibah di akhir masa sewa. ${ }^{15}$

Pada dasarnya menurut buku Kompilasi Hukum Ekonomi Syariah BAB XI tentang Ijärah pasal 324 Ayat 2, akad pemindahan kepemilikan pada ijärah muntahiyah bi al-tamlike hanya dapat dilakukan setelah akad tersebut

${ }^{14}$ Muhammad Syafi'i Antonio, Bank Syariah: Dari Teori ke Praktek, Jakarta: Gema Insani Press, 2001, hlm. 117.

15 Adiwarman A. Karim, Bank Islam Analisi Figh dan Kenangan, Jakarta: PT. Raja Grafindo Persada, 2004, hlm. 149. 
Implementasi Ijärah dan IMBT...

berakhir. ${ }^{16}$ Akan tetapi dalam perkembangan prakteknya pemindahan hak milik barang terjadi dengan salah satu dari dua cara berikut ini:

a. Pihak yang menyewakan berjanji akan menjual barang yang disewakan tersebut pada akhir masa sewa.

b. Pihak yang menyewakan berjanji akan menghibahkan barang yang disewaakan tersebut pada akhir masa sewa.

Adapun bentuk alih kepemilikan ijärah muntahiyah bi al-tamlīk antara lain:

a. Hibah di akhir periode, yaitu ketika pada akhir periode sewa aset dihibahkan kepada penyewa.

b. Harga yang berlaku pada akhir periode, yaitu ketika pada akhir periode sewa aset dibeli oleh penyewa dengan harga yang berlaku pada saat itu.

c. Harga ekuivalent dalam periode sewa, yaitu ketika membeli aset dalam periode sewa sebelum kontrak sewa berakhir dengan harga ekuivalen.

d. Bertahap selama periode sewa, yaitu ketika alih kepemilikan dilakukan bertahap dengan pembayaran cicilan selama periode sewa.

Akad ijärah muntahiyah bi al-tamlike pertama didapatkan pada tahun 1846 Masehi di Inggris, dan yang memulai bertransaksi dengan akad ini adalah seorang pedagang alat-alat musik di Inggris, dia menyewakan alat musiknya yang diikuti dengan memberikan hak milik barang tersebut, dengan maksud adanya jaminan haknya itu.

Setelah itu tersebarlah akad seperti ini dan pindah dari per individu ke pabrik-pabrik, dan yang pertama kali menerapkannya adalah pabrik Sanjar penyedia alat-alat jahit di Inggris. Selanjutnya berkembang, dan tersebar akad ini dengan bentuk khusus di pabrik-pabrik besi yang membeli barang-barang yang sudah jadi, lalu menyewakannya Kemudian setelah itu tersebar akad semacam ini dan pindah ke negara-negara dunia, hingga ke Amerika Serikat pada tahun 1953 M. Lalu tersebar dan pindah ke negara Perancis pada tahun

16 Mahkamah Agung RI, Kompilasi Hukum Ekonomi Syariah. Jakarta: Pusdiklat Peradilan Mahkamah Agung RI, 2009, 71. 
1962 M. Terus tersebar dan pindah ke negara-negara Islam dan Arab pada tahun 1397 H. ${ }^{17}$

\section{ljärah dan Leasing}

Menurut Yuliana, perbedaan ijärah dan leasing secara spesifik dapat diinterpretasikan sebagai berikut: ijärah sangat berbeda dengan leasing, objek jjärah dapat berupa suatu barang (harta fisik yang bergerak maupun tak bergerak dan harta perdagangan), serta objek ijärah dapat pula berupa jasa intingible ('amal) yang diberikan oleh manusia atau binatang. ${ }^{18}$ Karena pada dasarnya ijärah adalah akad yang mengatur pemanfaatan hak guna tanpa terjadi pemindahan kepemilikan, sehingga banyak yang menyamakan ijärah dengan leasing. Hal ini terjadi karena kedua istilah itu sama-sama mengacu hal ihwal sewa menyewa. Akan tetapi walaupun ada persamaan antara jaarah dengan leasing, terdapat beberapa karakteristik yang membedakannya, antara lain:19

a. Objek

Objek yang disewakan dalam leasing hanya berlaku untuk sewa menyewa barang saja, terbatas pada manfaat barang saja, tidak berlaku untuk manfaat tenaga kerja. Sedangkan objek yang disewakan dalam ijärah bisa berupa barang dan jasa/tenaga kerja. Ijärah bila diterapkan untuk mendapatkan manfaat barang disebut sewa menyewa dan untuk mendapatkan manfaat tenaga kerja/jasa disebut upah mengupah. Objek yang disewakan dalam ijärah adalah manfaat barang dan manfaat tenaga kerja. Dengan demikian, bila dilihat dari segi objeknya, ijarah mempunyai cakupan yang lebih luas daripada leasing.

b. Metode pembayaran

Dari segi metode pembayaran, leasing hanya memiliki satu metode pembayaran yaitu yang bersifat not contingent to formance artinya pembayaran tidak tergantung pada kinerja objek yang disewa. Pembayaran ijärah dapat dibedakan menjadi dua, yaitu ijärah yang pembayarannya tergantung pada kinerja objek yang disewa (contingent to formance) dan ijärah yang pembayarannya tidak tergantung pada kinerja objek yang disewa (not contingent to formance). Ijärah

${ }^{17}$ http:/ / www.direktoriislam.com. diakses 11 Maret 2014.

18 Indah Yuliana, Investasi Produk Kenangan Syariah, Malang: UIN- MALIKI Press, 2010, hlm. 164.

${ }^{19}$ Karim, Bank Islam..., hlm. 141. 
Implementasi Ijärah dan IMBT...

yang pembayarannya tergantung pada kinerja objek yang disewa disebut ijārah, gaji, sewa. Sedangkan ijärah yang pembayarannya tidak tergantung pada kinerja objek yang disewa disebut ju'älah atau success fee.

c. Pemindahan kepemilikan (transfer of title)

Dari aspek perpindahan kepemilikan dalam leassing dikenal dua jenis yaitu operating lease dimana tidak terjadi pemindahan kepemilikan baik di awal maupun di akhir periode sewa dan financial lease. Ijärah sama seperti operating lease yakni tidak ada transfer of title baik di awal maupun di akhir periode, namun pada akhir sewa dapat dijual barang yang disewakan kepada nasabah yang dalam perbankan syariah dikenal dengan ijärah muntabiyah bi al-tamlik. Harga sewa dan harga jual disepakati pada awal perjanjian.

\section{Aplikasi ljārah dan IMBT pada Bank BRI Syariah Cabang Yogyakarta}

Adapun ijärah dalam pembiayaan bank syariah untuk pengadaan barang ditambah keuntungan yang disepakati dengan sistem pembayaran sewa tanpa diakhiri dengan pemilikan. ${ }^{20}$ Sedangkan ijärah muntabiyah bi al-tamlïk dalam perbankan syariah ialah akad sewa menyewa barang antara bank (muäjir) dengan penyewa (mustajir) yang diikuti janji bahwa pada saat yang ditentukan kepemilikan barang sewaan akan berpindah kepada mustajir. Sedangkan harga sewa dan harga jual disepakati pada awal perjanjian. Hal ini selaras dengan perkataan Ibnu Qudamah mengenai ijarah, yaitu "wa kullu mā jäza tsamanan fì albay'i jāza 'iwadhan fi al-ijärah." "21

Lebih rincinya produk dan proses sewa (jjärah) pada perbankan syariah dapat dijelaskan pada beberapa tabel di bawah ini:

${ }^{20}$ Martono, Bank dan Lembaga Kenangan Lain, Yogyakarta: Ekonisia, 2002, hlm. 99.

21 Al-Athrom, Abdurrahman bin Shalih, al-Wasathah al-Tijäriyyah fi al-Mu'āmalah al-Mäliyyah, Riyadh: Dār Isybiyliyā, 1995, hlm. 160. 
Tabel 3.2

Produk Sewa

\begin{tabular}{|l|l|l|}
\hline No & Produk & Prinsip Syariah \\
\hline 1 & Sewa Beli & Ijārah Muntahiyah bi al-Tamlīk \\
\hline 2 & $\begin{array}{l}\text { Pembiayaan untuk } \\
\text { akuisisi aset }\end{array}$ & Ijārah Muntahiyah bi al-Tamlīk \\
\hline
\end{tabular}

Gambar 3.1

Skema Kerja Prinsip Ijārah

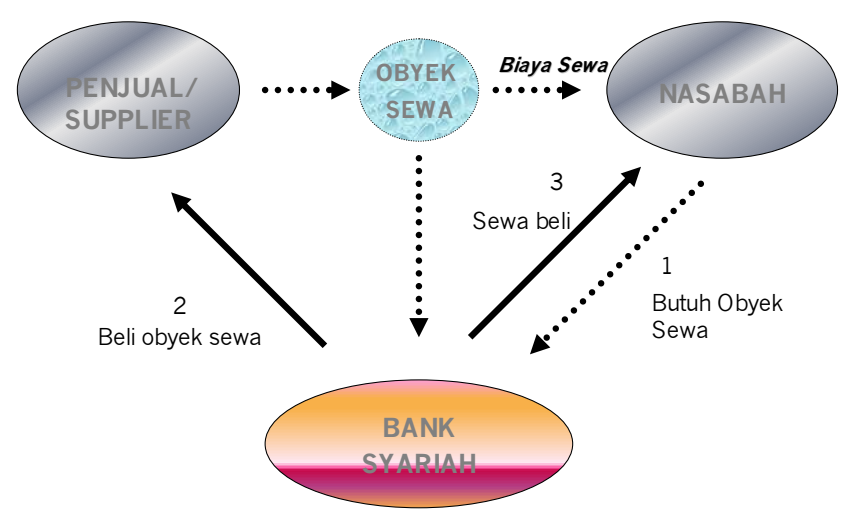

Sumber: Dokumentasi Bank BRI Syariah Cabang Yogyakarta

Gambar 3.2

Skema Kerja Prinsip Ijārah Muntahiyah bi al-Tamlīe.

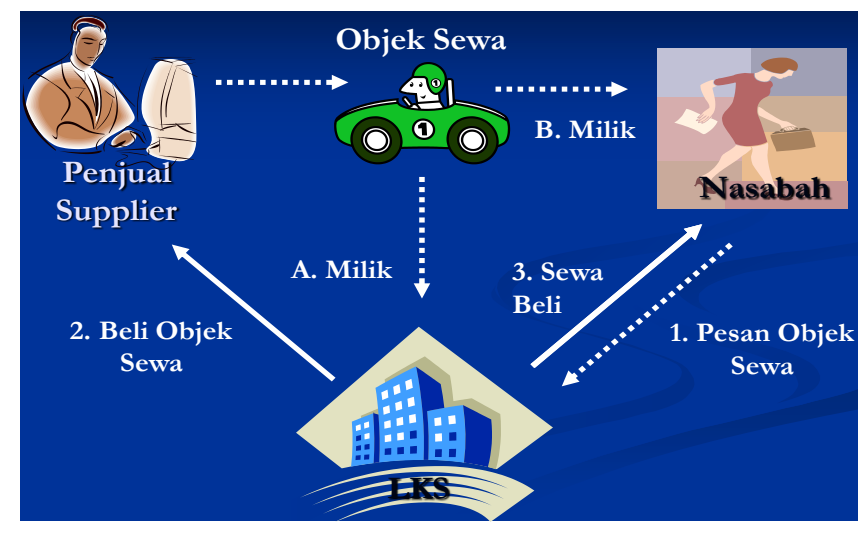

Sumber: Dokumentasi Bank BRI Syariah Cabang Yogyakarta 
Implementasi Ijärah dan IMBT...

Karim Syah menjelaskan bahwasannya dalam tataran syariah, Bank dianggap pemilik dari barang yang disewakan; oleh karena itu menurut logika, Banklah yang membeli barang dari suplier. Untuk itu diawal Perjanjian IMBT harus ditentukan bahwa Bank BRI Syariah memberi kuasa kepada nasabah untuk membeli barang yang akan menjadi objek ijärah. ${ }^{22}$ Dengan demikian di perjanjian IMBT akadnya adalah ijärah dengan wa'ad jual beli/hibah yang akan ditandatangani setelah ijärah berakhir (jika nasabah menghendakinya). Oleh karena itu perlu dilampirkan konsep perjanjian jual beli/hibah; juga dilampirkan konsep kuasa kepada Bank BRI Syariah untuk menjual aset jika pada akhir masa ijärah, nasabah tidak ingin memiliki aset. Kuasa jual diperlukan karena aset sejak masa ijarah sudah dicatatkan atas nama nasabah. Konsep kuasa jual ditandatangani setelah masa ijärah berakhir”.

Secara umum, kontrak ijärah bagaimana pun bentuknya, jika objeknya adalah barang yang tidak bergerak, Bank BRI Syariah akan membelinya untuk kepentingan nasabah, yang akan menyerahkan kepada bank suatu imbalan penyewaan dalam jangka waktu yang telah ditentukan, yang cukup untuk menutupi modal pokok pemula, dan bank akan memperoleh keuntungan dari aktifitas usaha, dan biasanya berakhir dengan perolehan nasabah untuk memiliki barang yang tidak bergerak tersebut. Dan jika berbentuk barang yang bergerak, Bank BRI Syariah juga akan membelinya dan menyewakannya kepada nasabah, di mana nasabah teresebut memiliki hak pilih ketika berakhirnya masa penyewaan, antara memiliki barang tersebut, membuat akad baru ataupun menggugurkannya berdasarkan persyaratan-persyaratan yang telah disepakati. Mengingat bahwasanya kontrak ini tidak diberlakukan pada bank syariah terhadap komoditas yang dapat berubah atau yang cepat habis (barang konsumtif).23 Oleh karena, pada dasarnya prinsip ijärah sama dengan prinsip muräbahah, perbedaannya hanya terletak pada objek transasksinya. Apabila objek transaksi muräbahah adalah barang, sedangkan pada ijarah objek transaksinya adalah barang dan jasa. ${ }^{24}$

\footnotetext{
${ }^{22}$ Iswahjudi A. Karim, "Pembiayaan Ijarah Muntahiyah Bitamlik", Paper, KarimSyah Law Firm. Jakarta, 2005, hlm. 5

23 http:/ / wmw.ekisonline.com 2 diakses 11 Maret 2014.

${ }^{24}$ Muhammad, Manajemen Bank Syariah, Yogyakarta: UPP STIM YKPN, 2011, hlm. 99.
} 
Penerapan pembiayaan ijärah dan ijärah muntahiyah bi al-tamlike (IMBT) di Bank BRI Syariah Cabang Yogyakarta memiliki kesamaan perlakuan dengan pembiayaan muräbahah. Kesamaan ini dapat dilihat dari kesamaan kategori akadnya, yaitu termasuk natural certainty contract, yang notabene adalah akad jual beli. Perbedaannya hanya pada objek yang diperjual-belikan, pada pembiayaan muräbahah objeknya hanya berupa barang sedangkan pada IMBT ialah barang dan jasa. Hal ini juga dibolehkan secara UU dalam pasal 19 Undang-Undang Nomor 21 tahun 2008 tentang Perbankan Syariah menyatakan bahwa kegiatan usaha Bank Umum Syariah salah satunya adalah menyalurkan pembiayaan penyewaan barang bergerak atau tidak bergerak kepada nasabah berdasarkan akad ijärah dan/atau sewa beli dalam bentuk ijärah muntahiyah bi al-tamlike (IMBT) atau akad lain yang tidak bertentangan dengan prinsip Syariah.

Salah satu keunggulan produk Bank BRI syariah adalah KPR BRISyariah iB. Pada tahun 2012, jumlah pembiayaan KPR BRISyariah iB adalah sebesar Rp. 1,39 triliun atau meningkat 25,3 \% dibandingkan tahun 2011 yang mencatat angka Rp. 1,11triliun. Peningkatan Pembiayaan KPR BRISyariah iB didorong adanya kerjasama strategis antara BRISyariah dengan developer dan agen-agen penjualan property serta adanya Program Kesejahteraan Karyawan (EmBP). Untuk meningkatkan Pembiayan KPR di kota-kota kedua, juga KPR Sejahtera bekerjasama dengan Kementerian Perumahan Rakyat (Kemenpera) RI melalui program Fasilitas Likuiditas Pembiayaan Perumahan (FLPP). ${ }^{25}$

Akan tetapi pada realitanya ijärah dan/atau IMBT ini jarang diaplikasikan oleh bank syariah, padahal dalam rangka diversifikasi produk pembiayaan, akad ini dipandang perlu untuk dioptimalkan implementasinya. ${ }^{26}$ Pada dasarnya akad ini bisa memberikan keuntungan baik bagi bank syariah ataupun nasabah. Keuntungan yang diperoleh nasabah misalnya ialah penambahan modal untuk meningkatkan investasi, sedangkan keuntungan bagi bank syariah, selain sebagai wujud diversifikasi produk, akad ini dapat mempercepat penyaluran dana dan meningkatkan pola investasi yang baik.

\footnotetext{
${ }^{25}$ Laporan Tahunan BRI Syariah tahun 2012, hlm. 32.

${ }^{26}$ Ali Muhayatsyah, "Ijarah dan Ijarah Muntahiya Bittamlike (IMBT) dalam Instrumen Keuangan Syariah”, Paper, Yogyakarta: UIN Sunan Kalijaga, 2012, hlm. 13.
} 
Implementasi Ijärah dan IMBT...

\section{Kesimpulan}

Dari pembahasan di atas, secara ringkas dapat dikatakan bahwa sementara ini yang menjadi landasan hukum ijärab bagi perbankan syariah yaitu fatwa Dewan Syariah Nasional Nomor 09/DSNMUI/IV2000 tanggal 13 April 2000 Tentang Pembiayan Ijarah. Dengan demikian, secara otomatis muamalah ini diperbolehkan oleh syar'i guna kemaslahatan manusia. Dengan alasan, bahwa Nabi pernah bersabda: antum a'lamu bi umüri dunyākum, dan juga para ulama berijtihad atas hal ini dengan apa yang telah disebutkan dari kaidahkaidah yang terdahulu, yakni "pada asalnya seluruh muamalah dan syarat-syarat yang terdapat di dalamnya itu boleh selama dalam muamalah tersebut tidak bertentangan dengan prinsip syariah, seperti tidak ada riba, gharar, maisir."

Adapun ijärah adalah termasuk salah satu perangkat permodalan dan produk pembiayaan yang penting guna mencapai suatu keuntungan (profit) yang diterapkan oleh perbankan syariah. Metode operasionalnya, bank syariah membeli apa yang diinginkan oleh nasabah yang berupa alat-alat perlengkapan, dan terkadang juga barang yang tidak bergerak (seperti rumah), dan bank syariah menyewakannya kepada mereka, dengan harga yang telah disepakati. Biasanya, pengembaliannya dengan cara angsuran tiap bulan atau dengan cara berkala sesuai dengan kesepakatan pada akad. Lalu bank syariah memberikan mereka pilihan di saat berakhirnya kontrak, untuk memiliki barang yang disewa dengan cara membelinya dari bank (ijärah muntabiyah bi al-tamlike), atau dengan menyerahkannya kembali kepada bank (ijārah). 


\section{DAFTAR PUSTAKA}

Ahmad Assalus, Ali, al-Iqtishäd al-Islämy wa al-Qadhāyà al-Fiqhiyyah al-Mu'ashirah, juz I, Beirut: Dār al-Tsaqafah, 1998.

Antonio, Muhammad Syafi'i, Bank Syariah: Dari Teori ke Praktek, Jakarta: Gema Insani Press, 2001.

Arruky, Muhammad, Qawāid al-Fiqh al-Islāmy min Khilāl Kitāb "al-Isyrāf 'alā Masāil al-Khilạ̈" al-Qādhi Abd al-Wahbāb al-Baghdadi al-Mäliky, jilid I, Damaskus: Dār al-Qalam, 1998.

Ascarya, Akad dan Produk Syari'ah, Jakarta: PT. Raja Grafindo Persada, 2007.

Athrom (al), Abdurrahman bin Shalih, al-Wasathah al-Tijaìyyah fi al-Mu'ämaläh al-Māliyyyah, Riyadh: Dār Isybiyliyāa, 1995.

Dokumentasi Bank BRI Syariah Cabang Yogyakarta

http:// wmw.brisyariah.co.id/?q=faq-perbankan-syariah, diakses 11 Maret 2014.

http:/ / www.direktoriislam.com, diakses 11 Maret 2014.

http:/ / www.ekisonline.com, diakses 11 Maret 2014.

Karim, Adiwarman A, Bank Islam Analisi Fiqh dan Kenangan, Jakarta: PT. Raja Grafindo Persada, 2004.

Karim, Iswahjudi A., "Pembiayaan Ijarah Muntahiyah Bitamlik", Paper. KarimSyah Law Firm. Jakarta, 2005.

Laporan Tahunan 2012 PT Bank BRISyariah

Martono, Bank dan Lembaga Keuangan Lain, Yogyakarta: Ekonisia, 2002.

Mishry (al), Rafiq Yunus, Ushül al-Iqtishäd al-Islämy, Cetakan ke-3, Damaskus: Dār al-Qalam, 1999.

Moeleong, Lexy J., Metodologi Penelitian Kualitatif, Bandung: Remaja Rosdakarya, 1990.

Muhammad, Manajemen Bank Syariah, Yogyakarta: UPP STIM YKPN, 2011.

Muhayatsyah, Ali, "Ijarah dan Ijarah Muntabiya Bittamlik (IMBT) dalam Instrumen Keuangan Syariah”, Paper, Yogyakarta: UIN Sunan Kalijaga, 2012.

Nazir, Habib dan Muh. Hasan, Ensiklopedi Ekonomi dan Perbankan Syariah. Bandung: Kaki Langit, 2004.

RI, Mahkamah Agung, Kompilasi Hukum Ekonomi Syariah. Jakarta: Pusdiklat Peradilan Mahkamah Agung RI, 2009. 
Implementasi Ijärah dan IMBT...

Sabiq, Sayyid, Fiqh al-Sunnah. jilid 3, Beirut: Dār al-Kitāb al-Araby, 1983.

Sutardi, Tatang, "Ijarah (Aplikasinya Pada Lembaga Keuangan Syari'ah)", Makalah, t.tp, 2008.

Tim Penulis Dewan Syari'ah Nasional (DSN) MUI, Himpunan Fatwa Dewan Syari'ah Nasional, Jakarta: PT. Intermasa, 2003.

Tim Penyusun Pedoman Akuntansi Perbankan Syariah Indonesia, Pedoman Akuntansi Perbankan Syariah Indonesia. Cet. 2. Jakarta: Ikatan Akuntan Indonesia (IAI), 2003.

Undang-Undang Nomor 21 tahun 2008 tentang Perbankan Syariah.

Yuliana, Indah, Investasi Produk Kenangan Syariah, Malang: UIN- MALIKI Press, 2010. 